This item was submitted to Loughborough's Research Repository by the author.

Items in Figshare are protected by copyright, with all rights reserved, unless otherwise indicated.

\title{
Context of use within usability activities
}

PLEASE CITE THE PUBLISHED VERSION

PUBLISHER

(c) Elsevier

LICENCE

CC BY-NC-ND 4.0

REPOSITORY RECORD

Maguire, Martin. 2019. "Context of Use Within Usability Activities". figshare. https://hdl.handle.net/2134/2206. 
Published in: Int. J. Human-Computer Studies (2001) 55, 453-483

doi: 10.1006/ijhc.2001.0486, Academic Press

Available online at: http://wwwidealibrary.com

\title{
CONTEXT OF USE WITHIN USABILITY ACTIVITIES
}

\author{
MARTIN MAGUIRE \\ Ergonomics and Safety Research Institute, Loughborough University \\ Holywell Building, Holywell Way, Loughborough, Leics, LE11 3UZ \\ Email: m.c.maguire@lboro.ac.uk
}

\section{ABSTRACT}

Designing for usability involves the activities of establishing user requirements for a new system or product, prototyping the user interface and testing it with representative users. However, before any usability design or evaluation activity can begin, it is necessary to understand the Context of Use for the product i.e. the goals of the user community, and the main user, task and environmental characteristics of the situation in which it will be operated. This paper describes the background to, and importance of, understanding Context of Use, and presents a process for performing a context analysis. It is based on the material from a workshop entitled 'Context of Use' presented at the Human Factors 2000 Symposium held at Loughborough University from 7th to 8th September 2000.

KEYWORDS: Context of Use, User, Task, Environment, Usability

\section{INTRODUCTION}

Context is an important concept in everyday life. People often provide context when writing postcards referring to the weather or holiday atmosphere. A knowledge of context can also help to explain why an art object such as Donatello's bronze statue of David was produced. As stated by Clark (1992), "such monumental figures were symbolic of a new-found confidence, and represented the freedom of Renaissance man from the medieval past". Context can also explain the background to an historical event, such the assassination of the Archduke Ferdinand in Sarajevo, which triggered war in Europe in 1914.... and of course words taken out of context often distort the speaker's intended meaning!

When a product (or system) is developed, it will be used within a certain context. It will be used by a user population with certain characteristics. The user will have certain goals and wish to perform certain tasks. The product will also be used within a certain range of technical, physical and social or organisational environments that may affect its use. 
When assessing a product from Human Factors point of view, there is a tendency to forget about the Context of Use. Information Technology (IT) products are often simply divided into those which are usable and have ‘ergonomic features' and those which are not. In fact it is incorrect to describe a product as ergonomic or usable, without also describing the context in which the product will be used - in other words, whom the product was designed for, what it will be used for, and where it will be used. A manufacturer might, for instance claim to have a very usable wristwatch. In fact it may only be usable in a certain range of contexts. The visual nature of the display might exclude people who are visually impaired. If the watch face lacks numbers and minute markings, this would make it unsuitable for tasks that requiring precise timings at a sports meeting. Without luminous or illuminated dial markings, the watch would not be suitable for use in the dark, whereas the use of reflective glass could impede viewing in bright light. Unless it is a watertight watch, it may be affected by rain and would certainly not work under water. This example shows the pitfalls of classifying a watch or any other product, as usable without referring to the context for which it is intended.

\section{THE DEVELOPMENT OF CONTEXT OF USE IDEAS}

\subsection{Early recognition of context}

In the field of natural science, the procedure of specifying, controlling and reporting the context in which measurement takes place has been routine for centuries. This procedure ensures that measurements are both meaningful and reproducible. Much of the early Human Factors work was performed in the military sector to test military components in unstable, harsh and extreme environments to represent battlefield conditions. In the field of Human Computer Interaction, it has been recognised for many years that the subjects and the tasks they carry out are likely to have a strong effect on the results of any system evaluation (Miller 1971).

\subsection{Realistic Users and Representative Tasks}

Many authors have emphasised the importance of selecting representative users and realistic tasks when carrying out user testing or evaluation of IT products (Neal and Simon 1984, Bury 1984, Rosenbaum 1989). Yet, if the literature is explored, it is often found that evaluation studies have either used unrepresentative subjects to carry out unrealistic tasks, or more commonly have failed even to report the nature of the subjects and the tasks they carried out. Often it is only after the study has been completed that effects of badly chosen subjects and tasks will be used to explain the 'odd' nature of the results.

\subsection{Task tool analysis}

By the early 1980's the differences in characteristics of particular user groups was well established. At the HUSAT Research Institute, several papers were produced characterising 
users of different kinds such as managers, clerical staff and specialists and discussing their needs. Eason (1981) presented the concept of the User-Task-Tool Analysis, highlighting the fact that the user and task characteristics have to be supported by characteristics of the tool i.e. the computer system or product.

\subsection{The work of Whiteside and colleagues}

In the mid-eighties there was an increase in awareness of context issues promoted by the work of Whiteside and his colleagues (Whiteside et al, 1988; Wolf, 1989). They found that although many products performed well in their laboratory experiments, they did not work when transferred to the real world. They put this down to the fact that the research often overlooked something crucial to the context in which the product would be used. The classical research methodology which they applied told them a lot about how to control variables, but little about how to select the most important variables in the first place. As a result of this they developed contextual research, where they would work with people carrying out real work in real situations rather than "artificially contrived" ones. In adopting this approach, Whiteside and his colleagues not only stimulated the discussion on the relative merits of laboratory versus field studies, but they also highlighted the importance of context issues.

\subsection{Laboratory versus field studies}

In fact, laboratory tests and field observations are both valuable methods for product evaluation which complement each other in the design process. The high degree of control and enhanced observation and video recording facilities associated with laboratory studies are particularly suited to summative evaluation, where the aim is to test whether a product meets certain predefined usability criteria. Field studies may then be used to "identify special problems associated with the integration of the product into the actual working environment" (Neal and Simon, 1984). Furthermore, field studies can tell you about the acceptability of a product, (i.e. whether the product will actually be used in real-life), whereas, in laboratory tests where the subjects generally have no option but to use the product, this is often not possible. Karat (1989) demonstrated the complementary nature of the two approaches by applying both laboratory and field studies in order to help iteratively design a security application. Interestingly, participants completed the tasks in 25\% less time in the field than when subjects completed similar tasks in laboratory conditions. Karat comments that although "there are possible problems in comparing the results of the different tests; however the benefits of having both types of test data outweigh the negative factors".

\subsection{The Usability Concept}

Usability became a well established concept in the IT world to represent the user friendliness of a system. However there was a need to establish the concept more clearly and to determine 
how to measure it. Shackel has done much work in this area, starting from his paper on The Concept of Usability in 1984, and through to his approach to defining usability in an operational manner published in 1991.

\subsection{The HUFIT toolset}

In 1985, a large scale European project was started within the EU Esprit I programme, called HUFIT (Human factors and Information Technology). This brought together a number of university institutions and major IT companies for the first time to try and integrate Human Factors methods into the IT design cycle. Within this project, the HUSAT Research Institute developed the Planning, Analysis and Specification Toolset (PAS), reported by Taylor (1990). This provided a process for identifying stakeholders and analysing their characteristics in order to develop a system to match them.

\subsection{The MUSiC Approach to Context}

The Esprit II MUSiC project built on the work of HUFIT. It aimed to develop standard measurement tools and methods for usability evaluation. An important concept that the project developed was the 'Measurement of USability in Context' (hence the name MUSiC). In an attempt to ensure that proper attention was paid to context issues, the MUSiC project advocated the following principles:

- The usability of a product depends on its Context of Use.

- $\quad$ Products should be designed for specific contexts.

- Measurement of usability must always be carried out in an appropriate context.

- Usability measurements should always be accompanied by a detailed description of the context of measurement.

Recording the context of measurement information allows other people to assess the validity or fairness of the measurement, and gives them the opportunity to generalise the results of the measurement to their own context if they see fit.

It was recognised with the MUSiC project that the guidelines and principles presented above can only be put into practice if suitable tools and methods are available. This led to the development of a Context of Use Questionnaire (Maissel, et al, 1991 and Thomas and Bevan, 1995) to describe a product's Context of Use and to specify an appropriate context of measurement.

\subsection{User requirements specification}

Establishing user requirements has tended to be an unstructured approach, unlike the formal process of system requirements engineering. The EU Telematics Applications Programme 
RESPECT (Requirements Engineering And Specification In Telematics) project (http://www.lboro.ac.uk/research/esri/staff/m-maguire.htm) developed a structured process for user requirements specification, and the translation of those requirements into specifications. An important component of this process was the specifying the future Context of Use for the system and to identify from this potential user requirements. Templates to support this activity are contained within the RESPECT Handbook (Maguire, 1998).

\subsection{Mobile environments}

The development of mobile technology such as portable devices or in-vehicle devices such as navigation systems has created new areas for Human Factors research. Usability evaluations of such products need to be carried out in realistic environments such as in a driving simulator or on the road. There is a need then to consider and define the Context of Use for such systems. Ross and Burnett (2000) provide a case study example of this type of study, and discuss the influence of different contextual factors on driver performance.

\subsection{Context of Use in standards}

The international standards community has also recognised the role of Context of Use within usability. The ISO 9241 standard Part 11 - Guidance on Usability (ISO, 1997) refers to the context of measurement in its definition of usability:

"Usability is the extent to which a product can be used with efficiency and satisfaction by specific users to achieve specific goals in specific environments."

This definition emphasises that the usability of a product is affected not only by the features of the product itself, but also on the specific circumstances in which a product is used. As defined by the standard:

"The Context of Use consists of the users, tasks and equipment (hardware, software and materials), and the physical and social environments in which a product is used."1

\footnotetext{
${ }^{1}$ Note: The term 'usability' is sometimes used to refer specifically to the usability attributes of a product, e.g. the ISO/IEC 9126 standard (ISO, 1991) defines it as a software quality and describes it as "A set of attributes of software which bear on the effort needed for use and on the individual assessment of such use by a stated or implied set of users". In contrast, usability in ISO 9241 - Part 11 (ISO, 1997) refers to the outcome of interaction in a context: i.e. the extent to which the intended goals of use of the overall system are achieved (effectiveness); the resources such as time, money or mental effort that have to be expended to achieve the intended goals (efficiency); and the extent to which the user finds the overall system acceptable (satisfaction). To distinguish the two concepts, the latter concept of usability has become known as: 'Quality in Use'.
} 
Context of Use is also incorporated into the ISO 13407 standard on user-centred design (ISO, 1999). This defines the process of understanding and specifying the Context of Use as one of the main stages in within the user-centred design process (see Figure 1 below):

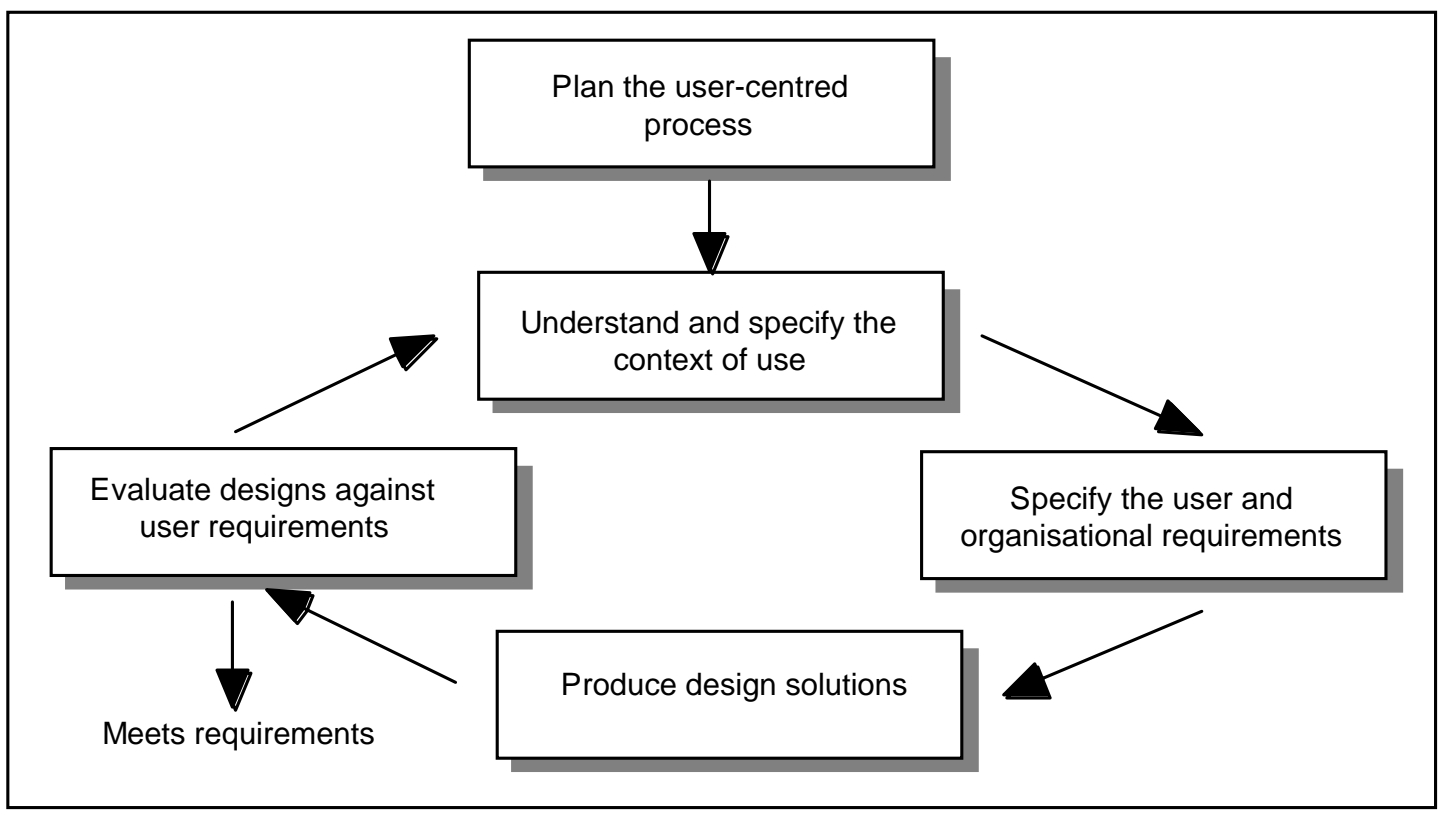

Figure 1. The User-Centred Design Cycle (from ISO13407)

\section{CONTEXT OF USE IN PRODUCT DESIGN}

\subsection{Benefits}

The analysis of the Context of Use helps to specify in a systematic way, the characteristics of the users, the tasks they will carry out, and the circumstances of use. The benefits of adopting this approach are as follows:

- $\quad$ Provides and understanding of the circumstances in which a product will be used.

- Helps to identify user requirements for a product.

- Helps address issues associated with product usability.

- $\quad$ Provides contextual validity of evaluation findings.

It also provides a system focussed approach which leads to a shared view among the design team.

\section{When and who may wish to perform Context of Use analysis?}

An understanding of the Context of Use of a product plays a role at different stages in the design process. Table 1 overleaf summarises who should be involved in specifying Context, at what stages in the lifecycle and the benefits that this will bring. 
Table 1. Producing a description of the Context of Use at different stages in the design process.

\begin{tabular}{|l|l|l|}
\hline \multicolumn{2}{|c|}{ Describing the Context of Use } \\
\hline Who & When & Why \\
\hline Procurer & Concept stage & $\begin{array}{l}\text { To aid specification of user } \\
\text { requirements. } \\
\text { To set usability goals and } \\
\text { acceptance criteria. }\end{array}$ \\
\hline Designer & $\begin{array}{l}\text { To ensure high quality design } \\
\text { by tailoring the product to the } \\
\text { context, and introducing early } \\
\text { assessment of usability. }\end{array}$ \\
\hline Usability analyst & Testing stage & $\begin{array}{l}\text { To match the Context of } \\
\text { Measurement to the Context of } \\
\text { Use. }\end{array}$ \\
\hline $\begin{array}{l}\text { Project manager or system } \\
\text { developer }\end{array}$ & Throughout the process & $\begin{array}{l}\text { To help them be aware of } \\
\text { usability issues throughout the } \\
\text { design process and to track the } \\
\text { achievement of usability } \\
\text { goals. }\end{array}$ \\
\hline
\end{tabular}

\section{SUMMARY OF CONTEXTUAL FACTORS}

This section provides a description of the main aspects of context. It is followed by a table listing the different contextual factors (Table 2).

\subsection{User goals and characteristics}

The central part of the Context of Use analysis of a system focuses upon the users of the product. A stakeholder analysis should be performed to identify all the different users of the system, and those who are also affected by it i.e. have a stake in its success. If the user population is composed of more than one user type, then an analysis should be completed for each type. Relevant characteristics of users also need to be described. These can include knowledge, skill, experience, education, training, physical attributes, and motor and sensory capabilities.

\subsection{Tasks}

Tasks are the activities undertaken to achieve a goal. Characteristics of tasks which may influence usability should be described e.g. the frequency and duration of the task. Tasks 
should not be described solely in terms of the functions or features provided by a product or system. Descriptions of the activities and steps involved in performing the task should be related to the goals which are to be achieved. For the purpose of specifying user requirements or evaluating usability, a key subset of contextual tasks will typically be selected to represent the significant aspects of the total set of tasks.

\subsection{Technical Environment}

The technical environment is the software and hardware which is used in conjunction with the product. The characteristics of the technical environment, (such as the speed of the processor, or the layout of keys on the keyboard), may have an affect on the usability of the product.

\subsection{Physical Environment}

The physical environment can have a profound effect on the usability of a product. Bad lighting or loud noise in the workplace may actually prevent the users from receiving vital feedback from the product. Likewise, even the location of the product in relation to user's workplace can magnify the effect of minor usability problems like having to reinsert cassettes frequently when a tape backup machine is located down the corridor (Brooke, 1986).

\subsection{Social or Organisational Environment}

The organisational environment will also affect the usability of a product. At a higher level, the attitudes of the organisation and its employees towards the introduction of an IT system, and the way work is monitored can affect whether a system is accepted and used to carry out the work. At a lower level the structure of the organisation, the way people work (individually and in groups), the availability of assistance, and the frequency of interruptions, are also likely to affect the usability of a product.

A list of contextual factors is presented in Table 2 overleaf. This draws from the work of Maissel et al (1991), Thomas and Bevan (1995) and the ISO 9241 part 11 standard (ISO, 1997). Context of Use information needs to be collected under each of the headings for the context in which the equipment is actually used (or is intended to be used). 
Table 2: Components of Context of Use analysis

\begin{tabular}{|c|c|c|}
\hline $\begin{array}{l}\text { SYSTEM REPORT and } \\
\text { STAKEHOLDER ANALYSIS }\end{array}$ & $\overline{\text { USER }}$ & TASK \\
\hline $\begin{array}{l}\text { System or product report } \\
\text { System or product name and } \\
\text { version } \\
\text { System or product description } \\
\text { and purpose } \\
\text { Main application areas } \\
\text { Major functions } \\
\text { Target market } \\
\text { Stakeholder report } \\
\text { User or stakeholder list } \\
\\
\text { User/stakeholder type 1, 2, etc. } \\
\text { Descriptions } \\
\text { User/Stakeholder type } \\
\text { User/Stakeholder role or goals } \\
\text { Potential benefits from system } \\
\text { or product } \\
\text { Costs of using system/product } \\
\text { Further analysis to be carried } \\
\text { out? (i.e. Context of Use } \\
\text { analysis) }\end{array}$ & $\begin{array}{l}\text { User name } \\
\text { User type } \\
\text { User role } \\
\text { Experience, knowledge and } \\
\quad \text { skills } \\
\text { Product experience } \\
\text { Related experience } \\
\text { Task knowledge } \\
\text { Organisational knowledge } \\
\text { Training } \\
\text { Input device skills } \\
\text { Qualifications } \\
\text { Language skills } \\
\text { Personal attributes } \\
\text { Age, Gender } \\
\text { Physical capabilities and } \\
\quad \text { limitations } \\
\text { Cognitive capabilities and } \\
\quad \text { limitations } \\
\text { Attitude and motivation }\end{array}$ & $\begin{array}{l}\text { Task list } \\
\text { Task 1 } \\
\text { Task 2, etc. } \\
\text { Task characteristics (per task) } \\
\text { Task name } \\
\text { Task goal/output } \\
\text { Task steps } \\
\text { Task frequency } \\
\text { Task duration } \\
\text { Task flexibility } \\
\text { Task dependencies } \\
\text { Physical and mental demands } \\
\text { Task output } \\
\text { Risks resulting from error } \\
\text { Safety critical demands }\end{array}$ \\
\hline \multicolumn{3}{|l|}{ ENVIRONMENT } \\
\hline $\begin{array}{l}\text { Technical environment } \\
\text { Hardware } \\
\text { Software } \\
\text { Network } \\
\text { Reference materials } \\
\text { Other equipment }\end{array}$ & $\begin{array}{l}\text { Physical environment } \\
\text { Workplace conditions } \\
\text { Atmospheric conditions } \\
\text { Auditory environment } \\
\text { Thermal environment } \\
\text { Visual environment } \\
\text { Environmental instability } \\
\text { Workplace design } \\
\text { Space and furniture } \\
\text { User posture } \\
\text { Location } \\
\text { Workplace safety } \\
\text { Health hazards } \\
\text { Protective clothing \& } \\
\text { equipment }\end{array}$ & $\begin{array}{l}\text { Organisational Environment } \\
\text { Structure } \\
\text { Group working } \\
\text { Work practices } \\
\text { Assistance } \\
\text { Interruptions } \\
\text { Management structure } \\
\text { Communications structure } \\
\text { Remuneration } \\
\text { Attitudes \& culture } \\
\text { Policy on use of computers } \\
\text { Organisational aims } \\
\text { Industrial relations } \\
\text { Job design } \\
\text { Job functions } \\
\text { Hours of work } \\
\text { Job flexibility } \\
\text { Performance monitoring } \\
\text { Performance feedback } \\
\text { Pacing/Autonomy/Discretion }\end{array}$ \\
\hline
\end{tabular}




\section{STAGES IN PERFORMING A USABILITY CONTEXT ANALYSIS}

Before the context study is begun, a small "usability team" should be set up consisting of at least one usability analyst, and one person with a good knowledge of the product, its intended users, and any constraints that may occur during the evaluation. It is also important to include someone of sufficient seniority to ensure that results of the study can be used to influence decision-making.

The results from a usability context analysis are typically captured in a set of Context Tables. The tables shown in section 6 of this paper (Tables 4 to 11) may be used to guide the process of collecting the context information. These tables give examples of typical output from analysing the Context of Use of a bank 'cashpoint machine' to illustrate the process.

One method of collecting information required in the Context Questionnaire is by holding a meeting of the usability team (a 'Context Meeting') and the people who can supply the required information - the stakeholders. This is a cost-effective way to elicit the information, but care must be taken to ensure that everyone has an opportunity to express their views, that views can be expressed freely without being affected by any power relationships which may exist between the participants, and that all views are accurately recorded.

Collecting information about the Context of Use of a product will also encourage other participants in the design process to consider context related issues, and to make explicit their views of the assumed Context of Use. Information is required for all the contextual components - users, tasks, and environments - and views may be requested from different departments. A list of personnel from whom information may be collected, or who may be invited to the Context Meeting are shown below in Table 3. 
Table 3: People who can provide information for a Context Study.

\begin{tabular}{|l|l|}
\hline \multicolumn{1}{|c|}{ Job Title } & \multicolumn{1}{c|}{ Role in product development } \\
\hline Customer & Commissions the product and sets requirements. \\
\hline Project manager & Responsible for the current product development activities. \\
\hline Product manager & Ultimately responsible for product development. \\
\hline Systems analyst & Identifies requirements and makes specifications. \\
\hline Designer/programmer & Codes the system. \\
\hline Marketing executive & Plans the promotion strategy and advertising. \\
\hline Technical author & Produces user documentation. \\
\hline Technical/user support & Produces user documentation. \\
\hline Users & $\begin{array}{l}\text { Help develop requirements, provide input and feedback on } \\
\text { prototype, require training and support. }\end{array}$ \\
\hline Quality manager & Responsible for the implementation of quality systems. \\
\hline Training manager & Defines user training requirements. \\
\hline Human Factors specialist & Responsible for usability \\
\hline
\end{tabular}

The following steps are involved in specifying the Context of Use for a product:

Step 1 : Describe the product or system (or concept) within a Project Report.

Step 2 : Identify users and other stakeholders for the product or system and select main user groups for further analysis

Step 3 : Describe the Context of Use

Step 4 : Identify important usability factors

Step 5 : $\quad$ Document potential requirements or test conditions

The five steps are described briefly below:

\section{Step 1 : Describe the product or system}

The development of a new or existing product will normally take place as a 'project'. It is important for the user requirements analyst to gain a high level understanding of the product and the reason for its development. It then becomes possible to understand how this will affect the user population. The information may be drawn from the initial statement of requirements. It may require reading and understanding the basic system proposal and asking for clarification where needed. The information is placed into a Project Table or Report.

The Project Report should be completed with the input from people with appropriate knowledge of the product. During development this would include product development managers, technical developers, sales and marketing staff and documentation and training material authors. When the product is being evaluated by a user organisation, the individuals 
involved could be product installation managers and technical support staff (cf. Table 4 for an example of a Project Report).

\section{Step 2 : Identify users and other stakeholders}

This section identifies the main users and stakeholders for the product in order to get a broad perspective on who is involved and affected by it. This will help to ensure that the needs of all involved are taken account of and, if required, the product is tested by them. Stakeholder analysis will identify:

- $\quad$ Primary user groups - those who use the system directly ('hands on') but may play no part in buying it. They include: end users, installers, maintainers.

- $\quad$ Secondary user groups - those who influence or are affected by the system, but may not be the actual users. They include: recipients, marketing staff, purchasers, support.

- $\quad$ For each groups of users and stakeholders, it is important to identify their main roles or task goals in order to find how useful and appropriate the product can be to them.

\section{Step 3 : Describe the Context of Use}

The next step is to document the Context of Use factors relating to the product. A set of tables has been produced to help elicit contextual information. Completion of the tables will help to create a comprehensive description of the Context of Use of a product. It guides the usability analyst through a structured breakdown of the relevant characteristics of the intended users, tasks and environments for which the product is being developed.

Knowledge of the Context of Use in itself will improve the design of a product It encourages designers to tailor the design to the specified real-world usage, and also to specify usability criteria so the product's usability can be assessed by evaluation throughout the design process (See the left-hand column within Tables 6-11, for example components of a Context of Use Description Report.)

\section{Step 4: Identify important usability factors}

The usability analyst then uses the Context Report Table to consider each of the components of the Context of Use, and decide whether or not they could affect the usability of the product. There are three possible responses to this question - 'yes', 'maybe' or 'no'. If the answer to this question is 'yes' then it is considered a critical component of the context. If the analyst is unsure whether a component will affect the usability of the product, he or she can reply 'maybe' to the question, and re-evaluate the response when it comes to step 3 of the procedure. If the answer is 'no', or if the component is not relevant to the product, then the analyst will not have to consider this component any further. Each decision has to be made based on the usability analyst's knowledge of HCI and ergonomics, and their experience of 
similar product evaluations (See the middle column within Tables 6-11 to show the identification of usability factors within the Context of Use Description.)

Critical components must be identified regardless of whether they can be represented in the Context of Evaluation. Other parties, such as consumer organizations, can then assess the validity and generalizability of the usability evaluation results. If it is not feasible to simulate any of the critical components, e.g. the availability of a Help Desk, then they will be omitted from the Context of Evaluation. The implementation of any of the critical components of the Context of Use in the Context of Evaluation depends upon scope of the usability evaluation and any financial and technical constraints.

\section{Step 5 : Document potential requirements or test conditions}

Having documented the Context of Use, and identified which are important components, the next step is to document (a) potential user requirements which follow on from the context information and (b) features of the usability evaluation study that should be included when the product is ready for testing.

For establishing user requirements, it is helpful to go through each usability component as part of a brainstorm and propose ideas that could address potential problems related to the context or that would match specific user needs or task characteristics. (See the right-hand column within Tables 6-11 to show potential user requirements labeled 'Req' or test conditions, labeled 'Test'.)

For establishing the characteristics of a usability test, each usability component (marked as 'yes' or 'maybe') may be classified as follows:

Ignore: no consideration given to setting the context item in the evaluation (e.g. do not care if subjects have glasses or not).

Monitor: context item not specified in the evaluation, but values will be monitored to avoid extreme conditions (e.g. no restriction on the proportion of male to female subjects but avoiding all men or all women).

Control: set value for the context item either fixing it e.g. lighting level, or varying it e.g. to meet a certain characteristic e.g. having subjects in 3 different age categories.

Evaluate: Creating of 2 or more evaluation condition for comparison e.g. equal numbers of subjects with and without previous experience of using touch screens. 


\subsection{Operationalising the decisions}

When the analyst has decided whether a component should be controlled, monitored or developed experimentally, etc., he or she must then specify exactly how this is to be carried out. For example, if the analyst has decided to provide assistance, then they need to decide how that can be provided in a standard format.

The next step is to develop an evaluation plan, which contains all relevant information from the Context Report giving specific details of how the evaluation will be performed. The plan should include:

- The number of users who will take part in the evaluation, what characteristics they should have (those which are to be Controlled), and what are to be ascertained as part of the evaluation (those which are to be Monitored).

- The tasks that the users will carry out as part of the evaluation and how the users will be introduced to it.

- The organisational conditions under which the users will work. For example, details here could include the number of and nature of any interruptions identified in the Context of Use as affecting usability.

- Details of the hardware, software and any network environment that will be provided during the evaluation.

- Description of the physical location and characteristics of the workplace.

Finally the evaluator should define the usability measures to be recorded and success criteria. This can take place early in design to form part of the product requirements. During detailed design, the main objective may be to obtain design feedback from informal evaluation of mock-ups and partial prototypes, in which case measures may not be required.

\section{AN EXAMPLE CONTEXT OF USE FOR AN ATM (BANK MACHINE)}

The following example documents the Context of Use for an Automated Telling Machine (ATM) which can provide simple banking services automatically to bank customers. These devices are also often called 'cashpoint machines' or 'bank machines'.

\subsection{Description of Product}

The aim of this fictional project is to produce a usable new generation of bank machine. The aim is to broaden the facilities available to existing ATM users and to encourage the $24 \%$ of bank customers who are non-users to consider using them. Reasons for non-use are: distrust 
of computers, anxiety about becoming targets for muggers and forgetting PINs or secret access numbers (Derbyshire, 1999). Another reason may be limited English language skills. In this example, the product constitutes the software and hardware that a customer sees when using an ATM. (See Table 4)

Table 4: Project summary

\begin{tabular}{|l|l|}
\hline \multicolumn{2}{|c|}{ Project summary } \\
\hline Product or system name & ATM 2000 - A new generation of bank machine \\
\hline $\begin{array}{l}\text { Aim or characteristics of the } \\
\text { system }\end{array}$ & $\begin{array}{l}\text { To provide an increased range of services to bank } \\
\text { customers via bank machines. } \\
\text { To offer a reliable service with the machines out of } \\
\text { operation for less time. }\end{array}$ \\
\hline Reason for system & $\begin{array}{l}\text { To offer a more secure service and safe service. } \\
\text { Tompromote the wider use of bank machines in a } \\
\text { competitive market. } \\
\text { To encourage new users such as the elderly and } \\
\text { disabled. }\end{array}$ \\
\hline $\begin{array}{l}\text { Scope of system/System } \\
\text { functions planned }\end{array}$ & $\begin{array}{l}\text { Banks and building societies. } \\
\text { Traditional services of cash withdrawal, statement, } \\
\text { balance, ordering chequebook etc. } \\
\text { Short on-line introductions for new users and } \\
\text { spoken instruction. } \\
\text { Possible new services include getting change, } \\
\text { requesting a loan, transferring money between } \\
\text { accounts etc. }\end{array}$ \\
\hline
\end{tabular}

\subsection{Stakeholder analysis}

An analysis of stakeholders has identified bank customers as the primary users with bank staff and machine maintenance staff as secondary users. Another group with a stake in the system are bank marketing staff. (See Table 5) 
Table 5: Result of stakeholder analysis

\begin{tabular}{|l|l|}
\hline \multicolumn{2}{|c|}{ Stakeholders and Task goals } \\
\hline SYSTEM NAME: ATM 2000 - A new generation of bank machine \\
\hline PRIMARY USERS & MAIN TASK GOALS \\
\hline Bank customer & $\begin{array}{l}\text { To obtain money } \\
\text { To request information (statement, or balance) } \\
\text { To order a cheque book } \\
\text { To perform account transactions and pay bills } \\
\text { To open and close an account } \\
\text { To obtain an alternative bank service e.g. order foreign } \\
\text { currency, set up a loan, set up savings, insurance or pension } \\
\text { scheme. } \\
\text { To top up a mobile phone. }\end{array}$ \\
\hline SECONDARY USERS & $\begin{array}{l}\text { Will be responsible for day-to-day maintenance, e.g. filling } \\
\text { machine with notes and paper (for receipts and statements), } \\
\text { correcting minor faults and reporting major faults. }\end{array}$ \\
\hline Bank staff & $\begin{array}{l}\text { Will perform routine maintenance every six months and will } \\
\text { come out to deal with major faults. }\end{array}$ \\
\hline Machine maintenance staff & Load ATMs with prefilled cassettes of notes. \\
\hline Security staff & MAIN TASK GOALS \\
\hline OTHER STAKEHOLDERS & $\begin{array}{l}\text { Will be concerned with deciding what services to offer on the } \\
\text { machine and what advertising to display when the machine is } \\
\text { not in use. }\end{array}$ \\
\hline Bank marketing staff &
\end{tabular}

\subsection{Recording Context of Use}

Tables 6 to 11 describe the Context of Use for the system or product for the bank customer. There are separate tables for the users themselves, their tasks, and the technical, physical and organisational environments. In each table:

Column 1 is used to record the characteristics of the context in which the ATM will be used. Column 2 is used to record whether each of the context items affects usability of the product (i.e. 'yes', 'no' or 'maybe').

Column 3 is used to record potential user requirements or evaluation conditions for components marked 'yes' and 'maybe'. 
Table 6: User characteristics context table

\begin{tabular}{|c|c|c|}
\hline Context of Use & $\begin{array}{c}\text { Affects } \\
\text { Usability? }\end{array}$ & $\begin{array}{l}\text { User requirements } \\
\text { or test conditions }\end{array}$ \\
\hline \multicolumn{3}{|l|}{$\begin{array}{l}\text { 1. USERS } \\
\text { 1.1 User Type }\end{array}$} \\
\hline $\begin{array}{l}\text { 1.1.1 Name of type } \\
\text { Bank customers }\end{array}$ & Maybe, control & $\begin{array}{l}\text { Test: Use members of the general } \\
\text { public }\end{array}$ \\
\hline $\begin{array}{l}\text { 1.1.2 User role (or aim) } \\
\text { To carry out simple bank transactions }\end{array}$ & $\begin{array}{c}\text { Yes } \\
\text { Control }\end{array}$ & $\begin{array}{l}\text { Req: Provide basic transactions and } \\
\text { new services in consistent and similar } \\
\text { way. } \\
\text { Test: Specify typical tasks to reflect } \\
\text { normal user aims. }\end{array}$ \\
\hline \multicolumn{3}{|l|}{ 1.2 Experience/Knowledge } \\
\hline $\begin{array}{l}\text { 1.2.1 Experience/knowledge with } \\
\text { system or product } \\
\text { Varies from none to regular daily use. }\end{array}$ & - & \\
\hline $\begin{array}{l}\text { 1.2.2 Experience/knowledge with } \\
\text { similar systems or products } \\
70 \% \text { of users will have used bank } \\
\text { machines and elsewhere. } \\
\text { Others will have limited or no } \\
\text { experience. }\end{array}$ & Monitor & $\begin{array}{l}\text { Req: Try to make the system conform } \\
\text { with any accepted ad hoc standards for } \\
\text { bank machines } \\
\text { Develop ways to introduce new users to } \\
\text { machine banking e.g. video } \\
\text { introductions in post, bank staff } \\
\text { support, speech instructions, etc. } \\
\text { Test: Check length of time card held } \\
\text { and frequency of use. }\end{array}$ \\
\hline $\begin{array}{l}\text { 1.2.3 Task knowledge } \\
\text { Nearly all experienced in withdrawing } \\
\text { cash over counter. Goal is essentially } \\
\text { the same but task process different (one } \\
\text { is self-service, the other is not). }\end{array}$ & Yes & $\begin{array}{l}\text { Req: Study bank counter exchanges for } \\
\text { new forms of transaction proposed and } \\
\text { reflect in self-service kiosk. } \\
\text { Test: Include some users who have } \\
\text { accounts but rarely visit banks. }\end{array}$ \\
\hline $\begin{array}{l}\text { 1.2.4 Organisational knowledge } \\
\text { Many customers will have little } \\
\text { knowledge of bank organisation. }\end{array}$ & - & \\
\hline $\begin{array}{l}\text { 1.2.5 Level of training } \\
\text { Mainly none. Some users may have } \\
\text { received introduction from bank staff }\end{array}$ & Ignore & $\begin{array}{l}\text { Req: Provide short interactive guide on } \\
\text { screen for new users, "help" facility to } \\
\text { support user, spoken instructions and } \\
\text { video to play at home. Ensure job } \\
\text { flexibility to allow bank staff to provide } \\
\text { support. } \\
\text { Test: Concentrate on testing without } \\
\text { providing equivalent human } \\
\text { introduction. }\end{array}$ \\
\hline $\begin{array}{l}\text { 1.2.6 Input device skills } \\
\text { Full range. Some motor impaired users } \\
\text { will have very limited skills }\end{array}$ & Yes & $\begin{array}{l}\text { Req: Develop speech interface for those } \\
\text { with limited keyboard skills. }\end{array}$ \\
\hline
\end{tabular}


Table 6 (continued): User characteristics context table

\begin{tabular}{|c|c|c|}
\hline Context of Use & $\begin{array}{c}\text { Affects } \\
\text { Usability? }\end{array}$ & $\begin{array}{l}\text { User requirements } \\
\text { or test conditions }\end{array}$ \\
\hline $\begin{array}{l}\text { 1.2.7 Qualifications } \\
\text { Any level }\end{array}$ & $\begin{array}{c}\text { Yes } \\
\text { Control }\end{array}$ & $\begin{array}{l}\text { Req: Design to be usable by people who } \\
\text { may have limited reading skills. } \\
\text { Test: Include some non-readers. }\end{array}$ \\
\hline $\begin{array}{l}\text { 1.2.8 Language skills } \\
\text { English will be main language. } \\
\text { Some areas of country will include up } \\
\text { to } 30 \% \text { of population where English is } \\
\text { second language. } \\
\text { Used by tourists, especially from EU. }\end{array}$ & Yes & $\begin{array}{l}\text { Req: Use English language and up to } 8 \\
\text { other language options, depending on } \\
\text { local area. Use simple terminology, } \\
\text { diagrams and pictures } \\
\text { Test: Include some for whom English } \\
\text { is second language. }\end{array}$ \\
\hline \multicolumn{3}{|l|}{ 1.3 Personal attributes } \\
\hline \multicolumn{3}{|l|}{ 1.3.1 Age } \\
\hline $\begin{array}{l}16 \text { upwards for main bank customers. } \\
\text { Accounts for } 12-15 \text { year old may } \\
\text { allow some use of bank machine. }\end{array}$ & $\begin{array}{c}\text { Yes } \\
\text { Control }\end{array}$ & $\begin{array}{l}\text { Req: Given particular consideration to } \\
\text { older user groups who may be more } \\
\text { reserved about new technology. } \\
\text { Test: Recruit } 25 \% \text { of users in each of } \\
\text { the following age categories: } 16-25,26- \\
40,41-70,70+.\end{array}$ \\
\hline \multicolumn{3}{|l|}{ 1.3.2 Gender } \\
\hline Roughly $50 \%$ male, $50 \%$ female & Maybe, control & $\begin{array}{l}\text { Test: Try to get an even balance } \\
\text { between males and females. }\end{array}$ \\
\hline \multicolumn{3}{|l|}{$\begin{array}{l}\text { 1.3.3 Physical capabilities and } \\
\text { limitations }\end{array}$} \\
\hline $\begin{array}{l}\text { Significant minority with visual, } \\
\text { hearing, speech, motor or mental } \\
\text { impairments. }\end{array}$ & Control & $\begin{array}{l}\text { Req: Ensure that system keyboard and } \\
\text { screen are placed at a standard height. } \\
\text { Use larger keys and short cut option. } \\
\text { Provide recess for wheelchair. } \\
\text { Test: Include wheelchair users, users } \\
\text { with motor control problems and with } \\
\text { visual impairment. }\end{array}$ \\
\hline \multicolumn{3}{|l|}{$\begin{array}{l}\text { 1.3.4 Cognitive capabilities and } \\
\text { limitations }\end{array}$} \\
\hline $\begin{array}{l}\text { Significant minority with memory and } \\
\text { other cognitive problems. }\end{array}$ & Control & $\begin{array}{l}\text { Req: Colour code or number certain } \\
\text { key group to reinforce sequence. } \\
\text { Provide voice prompts on request. } \\
\text { Allow user to cancel easily if unsure. } \\
\text { Test: Include users with cognitive } \\
\text { problems. }\end{array}$ \\
\hline \multicolumn{3}{|l|}{ 1.3.5 Attitude and motivation } \\
\hline Highly motivated to complete task. & No & \\
\hline
\end{tabular}


The following task scenarios are listed as typical examples of ATM usage:

Table 7: Selection of task scenarios

\begin{tabular}{|l|c|}
\hline \multicolumn{1}{|c|}{ Context of Use } & $\begin{array}{c}\text { Analyse } \\
\text { further }\end{array}$ \\
\hline $\begin{array}{l}\text { 2. TASKS } \\
\text { 2.1 Task name }\end{array}$ & \\
\hline 1. $\quad$ To withdraw a sum of money quickly. & Task T1 \\
\hline $\begin{array}{l}\text { 2. } \quad \text { To check balance, decide how much to withdraw and make } \\
\text { withdrawal. }\end{array}$ & Task T2 \\
\hline 3. $\quad$ To order a statement and/or cheque book. & Task T3 \\
\hline 4. $\quad$ To deposit notes or cheque into account. & Task T4 \\
\hline 5. $\quad$ To transfer funds from one account to another. & Task T5 \\
\hline 6. $\quad$ To pay a bill e.g. electricity, gas, telephone, TV licence. & Task T6 \\
\hline 7. $\quad$ To obtain change for a high value note. & Task T7 \\
\hline 8. $\quad$ Change PIN or password. & Task T8 \\
\hline 9. $\quad$ To set up a loan. & Task T9 \\
\hline 10. To deposit or order foreign currency. & Task T10 \\
\hline
\end{tabular}


The following table should be completed for each task to be analysed:

Table 8: Task characteristics description

\begin{tabular}{|c|c|c|}
\hline Context of Use & $\begin{array}{c}\text { Affects } \\
\text { Usability? }\end{array}$ & $\begin{array}{l}\text { User requirements } \\
\text { or test conditions }\end{array}$ \\
\hline \multicolumn{3}{|l|}{$\begin{array}{l}\text { 2. TASK T10 } \\
\text { 2.2 Task characteristics }\end{array}$} \\
\hline $\begin{array}{l}\text { 2.2.1 Task name } \\
\text { Order foreign currency. }\end{array}$ & - & \\
\hline $\begin{array}{l}\text { 2.2.2 Task goal or output } \\
\text { Obtain currency at an acceptable rate } \\
\text { of exchange.. }\end{array}$ & Yes, control & Test: Use as basis for test task \\
\hline $\begin{array}{l}\text { 2.2.3 Task breakdown } \\
\text { Step 1: Enter card } \\
\text { Step 2: Enter PIN } \\
\text { Step 3: Select “Order currency” } \\
\text { Step 4: Choose 'on screen' or 'printed'. } \\
\text { Step 5: Decide how much to withdraw. } \\
\text { Step 6: Enter amount. } \\
\text { Step 7: Take money and collect card }\end{array}$ & Yes & $\begin{array}{l}\text { Reqs: } \\
\text { - Notch/picture to show way to insert. } \\
\text { - Allow user to specify password as a } \\
\text { series of alphanumeric characters (to } \\
\text { be more memorable). } \\
\text { - Allow speech interaction. } \\
\text { - Do not time out too quickly. } \\
\text { - Having selected currency, show } \\
\text { current rate and rate change over } \\
\text { period of time (e.g. last few days) } \\
\text { - Provide range of standard currency } \\
\text { amounts to withdraw. } \\
\text { - Allow user to specify amount in UK or } \\
\text { foreign currency. } \\
\text { - Allow time lapse to allow user to put } \\
\text { money in pocket, purse or wallet. }\end{array}$ \\
\hline $\begin{array}{l}\text { 2.2.4 Task frequency } \\
\text { Variable. Average perhaps once every } \\
\text { few months.. }\end{array}$ & No & \\
\hline $\begin{array}{l}\text { 2.2.5 Task duration } \\
2 \text { - } 3 \text { minutes (varies with system } \\
\text { response times). }\end{array}$ & Yes, control & $\begin{array}{l}\text { Test: System could be tested with long } \\
\text { and standard system response times. }\end{array}$ \\
\hline $\begin{array}{l}\text { 2.2.6 Task flexibility } \\
\text { User may wish to simply obtain } \\
\text { currency without checking exchange } \\
\text { rates. Allow user to specify amount in } \\
\text { UK currency or in foreign currency. }\end{array}$ & Yes & $\begin{array}{l}\text { Req: Allow option selection in any } \\
\text { order. } \\
\text { Test: Both variations where user selects } \\
\text { currency and amount with and without } \\
\text { checking rate changes. }\end{array}$ \\
\hline $\begin{array}{l}\text { 2.2.7 Task dependencies } \\
\text { Bank account containing sufficient } \\
\text { cash. Bank Card. Knowledge of PIN } \\
\text { and withdrawal limit. }\end{array}$ & $\begin{array}{l}\text { Yes, } \\
\text { evaluation } \\
\text { condition }\end{array}$ & $\begin{array}{l}\text { Test: System could be tested when } \\
\text { account does not hold enough to } \\
\text { provide currency amount user requires. }\end{array}$ \\
\hline $\begin{array}{l}\text { 2.2.8 Physical/ mental demands } \\
\text { Low physical demand. } \\
\text { Low mental demand after initial use }\end{array}$ & No & \\
\hline 2.2.9 Risk resulting from error & & \\
\hline
\end{tabular}




\begin{tabular}{|l|l|l|}
$\begin{array}{l}\text { Loss of card. } \\
\text { Not receiving money required. }\end{array}$ & - & $\begin{array}{l}\text { Req: Provide means for user to register } \\
\text { problem at the time with the machine, } \\
\text { and to get "receipt" to allow checking } \\
\text { by bank staff. }\end{array}$ \\
\hline $\begin{array}{l}\text { 2.2.10 Safety critical demands } \\
\text { Generally not hazardous. Possible } \\
\text { robbery of people withdrawing. } \\
\text { Growing problem of fraud. }\end{array}$ & No & $\begin{array}{l}\text { Req: provide alert button for user to } \\
\text { press if they feel unsafe. This alerts } \\
\text { bank staff and suspends transaction. } \\
\text { Iris or finger print recognition for user } \\
\text { identification. }\end{array}$ \\
\hline
\end{tabular}


Table 9: Technical environment description

\begin{tabular}{|c|c|c|}
\hline Context of Use & $\begin{array}{c}\text { Affects } \\
\text { Usability? }\end{array}$ & $\begin{array}{l}\text { User requirements } \\
\text { or test conditions }\end{array}$ \\
\hline \multicolumn{3}{|l|}{ 3. TECHNICAL ENVIRONMENT } \\
\hline $\begin{array}{l}\text { 3.1 Hardware } \\
\text { ATM linked via network to bank's } \\
\text { computer. }\end{array}$ & Yes, control & $\begin{array}{l}\text { Req: Standard ATM terminal but } \\
\text { adapted to needs of disabled users. }\end{array}$ \\
\hline $\begin{array}{l}\text { 3.2 Software } \\
\text { Bespoke transaction software }\end{array}$ & Yes, control & $\begin{array}{l}\text { Req: Use flexible development software } \\
\text { to allow for changes } \\
\text { Include colour/graphic display to } \\
\text { increase attractiveness to customers. }\end{array}$ \\
\hline $\begin{array}{l}\text { 3.3 Network } \\
\text { Established bank communications } \\
\text { network. }\end{array}$ & - & \\
\hline $\begin{array}{l}\text { 3.3 Reference materials } \\
\text { Through post when card received. }\end{array}$ & Yes, control & $\begin{array}{l}\text { Test: System to be tested without } \\
\text { instructional materials, but } \\
\text { Req: Develop instruction card to send } \\
\text { to new customers in post. }\end{array}$ \\
\hline $\begin{array}{l}\text { 3.4 Other equipment } \\
\text { Headphones and handset for speech } \\
\text { interaction. }\end{array}$ & $\begin{array}{l}\text { Yes, evaluation } \\
\text { condition }\end{array}$ & $\begin{array}{l}\text { Test: Set up additional evaluation } \\
\text { conditions to test ATM with headphones } \\
\text { with microphone and handset. }\end{array}$ \\
\hline
\end{tabular}


Table 10: Physical environment description

\begin{tabular}{|c|c|c|}
\hline Context of Use & $\begin{array}{c}\text { Affects } \\
\text { Usability? }\end{array}$ & $\begin{array}{l}\text { User requirements } \\
\text { or test conditions }\end{array}$ \\
\hline \multicolumn{3}{|l|}{$\begin{array}{l}\text { 4. PHYSICAL ENVIRONMENT } \\
\text { 4.1 Workplace conditions }\end{array}$} \\
\hline $\begin{array}{l}\text { 4.1.1 Atmospheric Conditions } \\
\text { UK outdoor weather conditions }\end{array}$ & No & \\
\hline $\begin{array}{l}\text { 4.1.2 Auditory Environment } \\
\text { UK urban street. Noise will range } \\
\text { from quiet street at night to busy } \\
\text { shopping street heavy traffic }\end{array}$ & Yes, control & $\begin{array}{l}\text { Test: midrange for normal use. } \\
\text { Noisy conditions for auditory use. }\end{array}$ \\
\hline $\begin{array}{l}\text { 4.1.3 Thermal Environment } \\
\text { UK outdoor weather } \\
\text { Cold winter conditions to warm } \\
\text { summer. }\end{array}$ & Yes, ignore & $\begin{array}{l}\text { Test: Will simulate with winter clothing } \\
\text { - see below. }\end{array}$ \\
\hline $\begin{array}{l}\text { 4.1.4 Visual Environment } \\
\text { UK urban street } \\
\text { From night time with street lighting to } \\
\text { full sun. }\end{array}$ & $\begin{array}{l}\text { Yes, evaluation } \\
\text { condition }\end{array}$ & $\begin{array}{l}\text { Test: In normal light, darkened and } \\
\text { bright sunlight conditions. } \\
\text { Req: Self lit keys for night time use. } \\
\text { Shaded display to avoid glare. }\end{array}$ \\
\hline $\begin{array}{l}\text { 4.1.5 Environmental instability } \\
\text { None }\end{array}$ & - & \\
\hline \multicolumn{3}{|l|}{ 4.2 Workplace design } \\
\hline $\begin{array}{l}\text { 4.2.1 Space and furniture } \\
\text { ATM mounted } 1 \mathrm{~m} \text {. above ground, inset } \\
\text { in wall sometimes with small ledge } \\
\text { below. }\end{array}$ & Yes, control & Test: 1 metre above ground level \\
\hline $\begin{array}{l}\text { 4.2.2 User posture } \\
\text { Standing } \\
\text { Wheelchair users sitting. }\end{array}$ & Yes, control & $\begin{array}{l}\text { Test: Include standing and wheelchair } \\
\text { users. } \\
\text { Req: To have } 2 \text { machines, one for } \\
\text { standing and one for wheelchair use. }\end{array}$ \\
\hline $\begin{array}{l}\text { 4.2.3 Location } \\
\text { Street, public thoroughfares }\end{array}$ & $\begin{array}{l}\text { Yes, real or } \\
\text { control }\end{array}$ & $\begin{array}{l}\text { Test: Test outside of possible. } \\
\text { Otherwise set up lab simulating } \\
\text { environmental conditions. }\end{array}$ \\
\hline \multicolumn{3}{|l|}{ 4.3 Health and Safety } \\
\hline $\begin{array}{l}\text { 4.3.1 Health hazards } \\
\text { None }\end{array}$ & - & \\
\hline $\begin{array}{l}\text { 4.3.2 Protective clothing and } \\
\text { equipment } \\
\text { Winter clothing would include gloves, } \\
\text { muffs etc. }\end{array}$ & $\begin{array}{l}\text { Yes, } \\
\text { evaluation } \\
\text { condition }\end{array}$ & $\begin{array}{l}\text { Test: Include a test with users wearing } \\
\text { gloves. }\end{array}$ \\
\hline
\end{tabular}

Table 11: Organizational environment description 


\begin{tabular}{|l|c|l|}
\hline \multicolumn{1}{|c|}{ Context of Use } & \multicolumn{1}{c|}{$\begin{array}{c}\text { Affects } \\
\text { Usability ? }\end{array}$} & \multicolumn{1}{c|}{$\begin{array}{c}\text { User requirements } \\
\text { or test conditions }\end{array}$} \\
\hline $\begin{array}{l}\text { 5. ORGANISATIONAL } \\
\text { ENVIRONMENT } \\
\text { 5.1 Structure }\end{array}$ & Yes, control & Test: Evaluation based on single users \\
\hline $\begin{array}{l}\text { S.1.1 Group working } \\
\text { May be parent with children. }\end{array}$ & Yes, control & Test: No assistance \\
\hline $\begin{array}{l}\text { 5.1.2 Work practice } \\
\text { Not relevant }\end{array}$ & No & \\
\hline $\begin{array}{l}\text { 5.1.3 Assistance } \\
\text { Possibly available from bank staff or } \\
\text { member of public in queue }\end{array}$ & No & \\
\hline $\begin{array}{l}\text { 5.1.4 Interruptions } \\
\text { Usually none }\end{array}$ & & \\
\hline $\begin{array}{l}\text { 5.1.5 Management structure } \\
\text { Not relevant }\end{array}$ & & \\
\hline $\begin{array}{l}\text { 5.1.6 Communications } \\
\text { structure } \\
\text { Not relevant }\end{array}$ & & \\
\hline $\begin{array}{l}\text { 5.2 Attitudes and culture } \\
\text { All bank branches to have own ATM } \\
\text { and to encourage usage to reduce staff } \\
\text { time on routine transactions. }\end{array}$ & & \\
\hline $\begin{array}{l}\text { 5.2.2 Organisational aims } \\
\text { Not relevant. }\end{array}$ & & \\
\hline $\begin{array}{l}\text { 5.2.3 Industrial Relations } \\
\text { Not relevant. }\end{array}$ & & \\
\hline
\end{tabular}


Table 11 (continued): Organizational environment description

\begin{tabular}{|l|c|l|}
\hline \multicolumn{1}{|c|}{ Context of Use } & \multicolumn{1}{|c|}{$\begin{array}{c}\text { Affects } \\
\text { Usability ? }\end{array}$} & \multicolumn{1}{c|}{$\begin{array}{c}\text { User requirements } \\
\text { or test conditions }\end{array}$} \\
\hline 5.3 Job design/user control & - & \\
\hline $\begin{array}{l}\text { 5.5.1 Job functions } \\
\text { Not relevant }\end{array}$ & - & \\
\hline $\begin{array}{l}\text { 5.5.2 Hours of work } \\
\text { Not relevant }\end{array}$ & - & \\
\hline $\begin{array}{l}\text { 5.5.3 Job flexibility } \\
\text { Not relevant }\end{array}$ & No & \\
\hline $\begin{array}{l}\text { 5.5.4 Performance monitoring } \\
\text { PINS monitored, for security, together } \\
\text { with response speeds and number of } \\
\text { transactions per day. }\end{array}$ & Yes, control & $\begin{array}{l}\text { Test: } \text { Money and receipt will always be } \\
\text { given (i.e. no simulation of money or } \\
\text { paper running out). }\end{array}$ \\
\hline $\begin{array}{l}\text { 5.5.5 Performance feedback } \\
\text { Receipt of money and receipt }\end{array}$ & Yes, control or \\
ignore & $\begin{array}{l}\text { Test: Money and receipt will always be } \\
\text { given (i.e. no simulation of money or } \\
\text { paper running out). }\end{array}$ \\
\hline $\begin{array}{l}\text { 5.5.6 Pacing } \\
\text { Queue pressure during busy periods }\end{array}$ & $\begin{array}{l}\text { Test: } \text { May be sufficient to test with no } \\
\text { queue. }\end{array}$ \\
\hline $\begin{array}{l}\text { 5.5.7 Discretion decide to go into branch if user } \\
\text { feels unsafe or queue too long. }\end{array}$ & Yes \\
\hline
\end{tabular}

From the above tables, possible user requirements can be identified such as a recess for wheelchair access, speech output for visually impaired users, customisation features for rapid access, finger print for identification, visor appearing during sunny weather, buttons lighting during darkness, register button when faults occur, alarm button for security alert. The basic structure of a usability evaluation and different evaluation conditions can also be specified such as users operating the ATM without pre-training or instructions, with and without gloves, using auditory and manual input, and in different lighting conditions.

\section{CONCLUSION}

This paper has argued that the usability of a system or product depends on its Context of Use, so context analysis is an essential pre-requisite for any work on usability. An understanding of the Context of Use forms a useful input to the process of specifying usability requirements, constructing a design prototype which can be evaluated, and evaluating the prototype with typical end users. 


\section{REFERENCES}

Bevan, N. and Macleod, M., (1994) Usability measurement in context, Behaviour and Information Technology, 13, 132-145.

Brooke J. B. (1986). Usability Engineering in office product Development, Proceedings of In M. D. Harrison \& A. F. Monk, eds. People and Computers: Designing for Usability Proceedings of the Second Conference of the BCS HCI Specialist Group, 23-26 September 1986, 249-259, Cambridge: Cambridge University Press.

Bury K. F., (1984) The Iterative Development of Usable Computer Interfaces, Proceedings of the INTERACT '84 conference, 343-348.

Clark, J., (1992) The illustrated history of art, London: Mallard Press, ISBN: 0-79-245521-5.

Derbyshire, D. (1999). Cash machine phobia. Daily Mail, 14 July, p31.

Eason, K. D., (1981) A task-tool analysis of the manager-computer interaction. In: B. Shackel (ed.) Man-Computer Interaction, pp 289-307. Amsterdam: Sijthoff and Noordhoff.

ISO (1991) ISO 9126: Software product evaluation - Quality characteristics and guidelines for their use. International Standards Organisation. Available from the British Standards Institute, London.

ISO (1997) ISO 9241-11: Ergonomic requirements for office work with visual display terminals (VDTs). Part 11 - Guidelines for specifying and measuring usability.

International Standards Organisation. Also available from the British Standards Institute, London.

ISO (1999). ISO 13407: Human-centred design processes for interactive systems. Geneva: International Standards Organisation. Also available from the British Standards Institute, London.

Karat, C-M., (1989), Iterative usability testing of a security application. Proceedings of the Human Factors Society 33 ${ }^{\text {rd }}$ Annual Meeting, Vol. 1, pp. 273-277, October 16-20. Denver, CO, USA. Santa Minica, CA: Human Factors \& Ergonomics Society.

Maguire, M. C., (1998)User-centred requirements handbook, EC Telematics Applications Programme, Project TE 2010 RESPECT (Requirements Engineering and Specification in Telematics), WP4 Deliverable D4.2, Version 3.3, May 1998.

Maissel J., Dillon A., Maguire M., Rengger R. and Sweeney M., (1991) Context guidelines handbook. MUSiC Project Deliverable IF2.2.2, National Physical Laboratory, Teddington, UK.

Miller, R. B., 1971, Human Ease of Use Criteria and Their Tradeoffs, IBM Technical Report No. TR 00.2185. 12 April, Ploughkeepsie, NY: IBM Corporation.

Neal, A.S. and Simon, R.M., 1984, Playback: A Method for Evaluating the Usability of Software and its Documentation, IBM Systems Journal, 23, 1, 82-96. 
Rosenbaum, S. 1989, Selecting Appropriate Subjects for Documentation Usability Testing, In: Work with Computers: Organizational, Management, Stress and Health Aspects, Smith M.J. and Salvendy G. (eds.) Amsterdam: Elsevier Science Publishers, 620-627.

Ross, T., and Burnett, G. (2000) Evaluation of the human-machine interface for complex system interaction: a case study in vehicle navigation systems. (Currently being considered for IJHCS special issue).

Shackel B. (1984) The concept of usability. In: J. L. Bennet, D. Carver, J. Sandelin and M. Smith (eds.) Visual Display Terminals: Usability Issues and Health Concerns, Englewood Cliffs, NJ: Prentice-hall, 45-88.

Shackel B. (1991) Usability - context, framework, definition, design \& evaluation. In Human Factors for Informatics Usability, B. Shackel and S. J. Richardson (eds.); pp21-37, Cambridge: Cambridge University Press. ISBN 0-521-36570-8.

Thomas, C. and Bevan, N. (1995) Usability context analysis: a practical guide, National Physical Laboratory, Teddington, Middlesex, TW11 0LW, UK.

Taylor, B. (1990) The HUFIT Planning, Analysis and Specification Toolset, HumanComputer Interaction - INTERACT'90 conference proceedings, 27-31 August, D. Diaper, G. Cockton, D. Gilmore and B. Shackel (eds.) Amsterdam: North-Holland, pp371-376, ISBN 0-444-88817-9.

Whiteside, J. Bennett, J. Holtzblatt, K. (1988) Usability Engineering: Our Experience and Evolution, In: Helander, M. (ed.) Handbook of Human-Computer Interaction, Amsterdam: Elsevier, 791-817.

Wolf, C.G. (Organiser) 1989, The Role of Laboratory Experiments in HCI : Help, Hindrance or Ho-hum? (Panel), Proceedings of CHI'89 conference, Austin, Texas, 30 April - 4 May 1989, ACM, New York, 265-268.

\section{Acknowledgement}

The author is grateful to his colleagues who were co-developers of Context of Use concepts and methods within the Esprit MUSiC project. At the HUSAT Research Institute, these included: Dr Andrew Dillon, Dr Marian Sweeney and Ms Clare Davies. At the National Physical Laboratory's Usability Department (now Serco Usability Services) they included: Dr Nigel Bevan, Jonathan Maissel, Ralph Rengger , Miles Macleod, Richard Corcoran and Cathy Thomas. The author would also like to thank Gordon Allison for inviting him to present the Context of Use workshop at Human Factors 2000 and to Emeritus Professor Brian Shackel for encouraging him to write it up as a paper. 